\title{
TRADISI UPACARA RITUAL SIRAMAN SEDUDO SEBAGAI WUJUD PELESTARIAN NILAI-NILAI SOSIAL
}

\author{
Wikan Sasmita \\ Program Magister Pendidikan Pancasila dan Kewarganegaraan Universitas Negeri Malang \\ Jl. Semarang No. 5 Malang \\ Email :wikansadewo@yahoo.co.id
}

\begin{abstract}
The purpose of writing this article is to describe the implementation of ritual ceremonies and the manifestation of the preservation of social values in the ritual ceremonies of the Sedudo ritual shower. The study uses a qualitative approach. Data collection using interviews and documentation. Data analysis is carried out by collecting data, reducing data, presenting data, and drawing conclusions. The procedure for implementing the Sedudo Siraman ritual ceremony is (1) sacred dance, (2) 15 girls salute / pray for supplication, (3) the Regent gives klenting, (4) klenting is brought to the spring / pool under the Sedudo grojogan, (5) klenting is left to the junkies, (6) the men fill the klenting with water and are handed over to the princesses, (7) holy water is handed over to the caretaker, (8) caretakers and village elders keep the water in the village tomb, (9) remarks and inauguration by the Regent, (10) reciting prayers, (11) bathing together. This form of social values is original in the community of Nganjuk district. The social values contained in the implementation of the Sedudo Siraman ritual ceremony are the value of tolerance, the value of compassion, the value of mutual cooperation, the value of harmony, the value of togetherness, the value of cooperation, and family values.
\end{abstract}

Keywords: sedudo shower, social value, ritual traditions

\begin{abstract}
Abstrak: Tujuan penulisan artikel ini adalah mendeskripsikan pelaksanaan upacara ritual dan wujud pelestarian nilai-nilai sosial dalam upacara tradisi ritual siraman Sedudo. Kajian menggunakan pendekatan kualitatif. Pengumpulan data menggunakan wawancara dan dokumentasi. Analisis data dilaksakan dengan pengumpulan data, reduksi data, penyajian data, dan penarikan kesimpilan. Prosedur pelaksanaan upacara ritual Siraman Sedudo yaitu (1) tari sakral, (2) 15 gadis memberi hormat/sembah mohon do'a restu, (3) Bupati memberikan klenting, (4) klenting dibawa ke sendang/ kolam di bawah grojogan Sedudo, (5) klenting diserahkan kepada para jejaka, (6) para jejaka mengisi klenting dengan air dan diserahkan kepada para puteri, (7) air suci diserahkan kepada juru kunci, (8) juru kunci dan sesepuh desa menyimpan air suci di makam desa, (9) sambutan dan peresmian oleh Bupati, (10) pembacaan do'a, (11) mandi bersama. Wujud nilai-nilai sosial ini merupakan asli ada di Maysarakat kabupaten Nganjuk. Nilai-nilai sosial yang terkandung dalam pelaksanaan upacara ritual Siraman Sedudo adalah nilai toleransi, nilai kasih sayang, nilai gotong royong, nilai kerukunan, nilai kebersamaan, nilai kerjasama, dan nilai kekeluargaan.
\end{abstract}

Kata Kunci: siraman sedudo, nilai sosial, tradisi ritual.

Negara Indonesia merupakan negara yang memiliki banyak adat dan kebudayaan. Adat dan kebudayaan itu telah lahir bersama dengan peradaban masyarakatnya. Adat adalah wujud ideal dari kebudayaan. Sifatnya abstrak,tak dapat diraba atau difoto (Koentjaraningrat, 2015:6). Kebudayaan dalam arti amat luas, yaitu seluruh total dari pikiran, karya, dan hasil karya manusia yang tidak berakar kepada nalurinya, dan yang karena itu hanya bisa dicetuskan oleh manusia sesudah suatu proses belajar (Koentjaraningrat, 2015:2). Hal ini dikarenakan oleh adanya faktor yang mempengaruhi terciptanya budaya dan adat kebiasaan antara lingkungan geografis, situasi, dan kondisi masyarakat yang bermukim, serta pola pikir masyarakat itu sendiri (Rohmah, 2015:5). 
Kebudayaan pada masa lampau dan pada masa sekarang yang mengalami pergeseran dan bahkan perubahan. Perubahan ini menyebabkan asimilasi budaya dan bahkan akulturasi budaya pada daerah yang menjadi obyek maupun subjek kebiasaan masyarakat pendatang.

Letak geografis akan mempengaruhi budaya dan adat kebiasaan oleh sebab itu Nganjuk merupakan Kabupaten kecil di Jawa Timur dengan Luas wilayah 1,224.25 $\mathrm{Km}^{2}$. Berada di antara $-7^{0}$ 20' sampai dengan $7^{0}$ 50' Lintang Selatan dan $111^{\circ}$ sampai dengan $112^{0} 13$ Bujur Timur. Dengan posisi demikian, wilayah Nganjuk bagian utara dibatasi oleh pegunungan Kedeng yang mempunyai ketinggian antara 60 Meter s/d 300 Meter yang berbatasan langsung dengan Kabupaten Bojonegoro. Di sebelah barat daya merupakan lereng pegunungan Wilis dengan ketinggian antara 1000 Meter sampai dengan 2300 Meter yang merupakan berbatasan langsung dengan Kabupaten Kediri, sedangkan daerah tengah merupakan dataran rendah dengan ketinggian rata-rata berkisar antara 60 Meter sampai 140 Meter dari permukaan laut, di wilayah tengah ini merupakan pusat dari peradapan kabupaten Nganjuk (Harimintadji, 1994:27).

Di lereng Pegunungan Wilis terdapat sebuah desa bernama Ngliman yang berda di Kecamatan Sawahan, merupakan pembagian kecamatan di wilayah Kabupaten Nganjuk. Awal mulanya desa ini merupakan desa yang sangat terpencil terletak di lereng Gunung Wilis yang mempunyai ketinggian 1.333 Meter dari permukaan air laut berhawa sejuk dan bahkan kadang-kadang berkabut (Harimintadji, 1994:111).

Desa Ngliman yang terletak di sebelah selatan Kota Nganjuk $( \pm 25 \mathrm{Km}$ dari Pusat Kota) disebelah utaranya gunung Wilis memiliki beberapa air terjun, diantaranya air terjun Singokromo, Segunting, Cagak, Selawe, Jeruk, Selanjur, Banyuiber, Banyupahit, Banyu Cemoro Kandang, dan Sedudo (Harimintadji, 1994:105). Letak geografis merupakan faktor yang mempengaruhi terciptanya budaya dan adat kebiasaan dan juga di dorong oleh, situasi, dan kondisi masyarakat yang bermukim, serta pola pikir masyarakatmaka akan mewujudkan suatu kebudayaan.

Wujud dari kebudayaan itu sendiri salah satunya berupa fisik dari aktivitas, perbuatan, dan karya semua manusia. Aspek fisik dari suatu religi sebagai suatu unsur dari kebudayaan yang universal adalah gedung atau bangunan tempat pemujaan (Koentjaraningrat, 2015:8). Religi merupakan suatu system yang terdiri dari : 1) Emosi keagamaan yang menyebabkan manusia itu bersikap religious; 2) Sistem keyakinan yang mengandung segala keyakinan serta bayangan manusia tentang sifat-sifat Tuhan, tentang wujud dari alam gaib (supernatural); serta segala nilai, norma, dan ajaran religi yang bersangkutan; 3) Sistem ritus dan upacara yang merupakan usaha manusia untuk mencari hubungan dengan Tuhan, dewa-dewa, atau makhluk-makhluk halus yang mendiami alam gaib; 4) Umat atau kesatuan sosial yang menganut system keyakinan tersebut dalam sub 2, dan yang melaksanakan system ritus dan upacara tersebut dalam sub 3 (Koentjaraningrat, 2015 : 157).

Siraman sedudo merupakan suatu Upacara ritual yang dilaksanakan setiap satu tahun sekali yaitu pada bulan Suro dan tepat pada tanggal 1 Suro dalam kalender Jawa atau dalam kalender Islam adalah bulan Muharram. Upacara Ritual sering disebut juga upacara keagamaan.Upacara ritual merupakan kegiatan yang dilakukan sekelompok masyarakat yang diatur dengan hukum masyarakat yang berlaku (Rohmah, 2015:6). Menurut cerita kata Sedudo berasal dari kata "Se" dan "Dudo". "Se" berarti satu, "Dudo" berarti orang yang sudah tidak mempunyai istri atau sengaja tidak beristri (Harimintadji, 1994:108). Menurut kepercayaan penduduk Sang Dudo tersebut ialah orang yang membuka (Cikal Bakal) Desa Ngliman yang setiap hari digunakan sebagai tempat mandi Sang Dudo, maka tempat itu kemudian diberi nama Sedudo. Sebagai peghormatan dan penghargaan terhadap Sang Dudo yang dianggap sebagai cikal bakal desa Ngliman itu, kebiasaan mandi di air terjun diikuti oleh warga desa Ngliman. Hanya saja pelaksanaan/kebiasaan mandi yang sudah mentradisi itu tidak dilaksanakan tiap hari, tetapi dilaksanakan setahun sekali yang kemudian disebut Upacara Mandi/Siraman (Harimintadji, 1994:109). Selain sebagai penghormatan dan penghargaan terhadap Sang Dudo kebiasaan Upacara Siraman ini, dipercaya atau diyakini bahwa air terjun Sedudo adalah air suci yang mengandung banyak kasiat untuk kesehatan dan keberuntungan.

Pelaksanaan upacara ritual siraman sedudo warga desa Ngliman berbondong-bondong menyemarakkan dalam hal persiapan sebelum dan sesudah pelaksanaan upacara ritual mandi 
siraman. Berangkat dari kepercayaan ini untuk masyarakat Ngliman secara turun temurun, dari generasi-kegenerasi melestarikan tradisi mandi Sedudo yang sudah beratus-atus tahun (Harimintadji, 1994:109). Dalam menyemarakkan upacara Siraman Sedudo sebelum dan sesudah pelaksanaan adanya nilai sosial yang menjadi penggerak masyarakat. Nilai sosial merupakan gambaran mengenai apa yang diinginkan, pantas, berharga, memengaruhi perilaku sosial dari orang yang memiliki nilai tersebut (Handoyo dkk, 2015:44). Oleh karena Upacara Ritual Mandi Siraman Sedudo sudah beratus tahun lamanya maka hal ini sudah menjadi nilai yang mendarah daging bagi masyarakat desa Ngliman pada khususnya dan masyarakat Kabupaten Nganjuk pada umumnya. Nilai yang telah menjadi menjadi kepribadian dan kebiasaan sehingga seseorang melakukannya tanpa melalui proses berfikir atau proses pertimbangan (Anwar dkk, 2013:191). Di lingkungan masyarakat desa Ngliman ternyata muncul beberapa nilai yang menjadi wujud dari pengalaman yang menjadi nilai sosial yang tumbuh dalam diri septiap jiwa individu, rasa simpati dan empati semakin tinggi sehingga menurunkan sikap egonya yang individualisti menjunjung nilai-nilai sosial dengan bekerjasama menyemarakkan dalam persiapan sebelum dan sesudah pelaksanaan Upacara Ritual Mandi Siraman. Nilai yang terkandung dalam Pelaksanaan Upacara Ritual Siraman Sedudo yaitu terdiri dari berbagai macam di antaranya adalah nilai toleransi, nilai kasih sayang, nilai gotong royong, nilai kerukunan dan kebersamaan, nilai kerjasama, dan nilai kekeluargaan (Zubaedi, 2006:13).

Kata Tradisi menurut kamus besar bahasa Indonesia KBBI adalah adat kebiasaan turuntemurun (dari nenek moyang) yang masih dijalankan dalam masyarakat. Sedangkan Menurut Coomans, M, (1987:73) Tradisi adalah suatu gambaran sikap dan perilaku yang berproses dalam waktu lama dan dilakukan secara turun dimulai dari nenek moyang. Hal ini sesuai dengan apa yang di jabarkan dalam Buku Nganjuk dan Sejarahnya bahwa Tradisi Upacara Ritual Siraman Sedudo telah di laksanakan oleh masyarkat desa Ngliman secara turun temurun, dari generasikegenerasi melestarikan tradisi mandi sedudo yang sudah berlangsung beratus-ratus tahun (Harimintadji, 1994:109).

Kata Upacara menurut kamus besar bahasa Indonesia KBBI adalah perbuatan atau perayaan yang dilakukan atau diadakan sehubungan dengan peristiwa penting. Peristiwa penting yang dimaksud disini adalah tidak lain Upacara Siraman Sedudo. Upacara Siraman sedudo ini dapat diartikan sebagai Upacara Adat. Upacara adalah sistem aktivitas atau rangkaian atau tindakan yang ditata oleh adat atau hukum yang berlaku dalam masyarakat yang berhubungan dengan berbagai macam peristiwa tetap yang biasanya dalam masyarakat yang bersangkutan (Koentjaraningrat, 1980:140). Merujuk pada peristiwa dan tempat Ritual Upacara Siraman Sedudo ialah tidak lain adalah di lereng gunung Wilis berupa Air terjun yang di anggap suci. Hal ini diceritakan pula bahwa air terjun ini dianggap suci dan mempunyai nilai magis yang tinggi (Harimintadji, 1994:109). Dalam pelaksananan upacara adat ini memiliki beberapa unsur diantaranya: (1) Tempat berlangsungnya upacara, tempat yang digunakan untuk melangsungkan suatu upacara biasanya adalah tempat keramat atau bersifat sacral/suci, tidak setiap orang dapat mengunjungi tempat tersebut. Tempat tersebut hanya dikunjungi oleh orang-orang yang berkepentingan, dalam hal ini adalah orang yang terlibat dalam pelaksanaan upacara seperti pemimpin upacara; (2) Saat berlangsungnya upacara/waktu pelaksanaan, waktu pelaksanaan upacara adalah saat-saat tertentu yang dirasakan tepat untuk melangsungkan upacara; (3) Benda-benda atau alat dalam pelaksanaan upacara adalah sesuatu yang harus ada semacam sesaji yang berfungsi sebagai alat dalam sebuah upacara adat; (4) Orang-orang yang terlibat didalamnya, orang-orang yang terlibat dalam upacara adat adalah mereka yang bertindak sebagai pemimpin jalanya upacara dan beberapa orang yang paham dalam ritual upacara adat (Koentjaraningrat, 1967: 241).

Unsur-unsur ini akan membentuk nilai sosial diantara masyarakat desa Ngliman. Oleh karena nilai adalah salah satu unsur dasar pembentukan orientasi budaya, nilai melibatkan konsep budaya yang menganggap sesuatu yang menganggap sesuatu itu sebagai baik atau buruk, benar atau salah, adil atau tidak adil, cantik atau jelek, bersih atau kotor, berharga atau tidak berharga, cocok atau tidak, dan baik atau kejam (Liliweri, 2014:55).

Keberadaan Air terjun pada mulanya sebagai proses alam biasa, namun dalam perkembanganya tidak terlepas dari cerita misteri yang kemudian mentradisi. Seperti halnya crita yang mewarnai air terjun sedudo ini, yang kemudian melatar 
belakangi lahirnya upacara mandi/siraman Sedudo (Rohmah, 2015:6). Menurut cerita Kata sedudo berasal dari kata "Se" dan "Dudo". "Se" berarti satu, "Dudo" berarti orang yang sudah tidak mempunyai istri atau sengaja tidak beristri (Harimintadji, 1994:108). Menurut kepercayaan penduduk Sang Dudo tersebut ialah orang yang membuka (Cikal Bakal) Desa Ngliman yang setiap hari digunakan sebagai tempat mandi Sang Dudo, maka tempat itu kemudian diberi nama Sedudo. Sebagai peghormatan dan penghargaan terhadap Sang Dudo yang dianggap sebagai cikal bakal desa Ngliman itu, kebiasaan mandi di air terjun diikuti oleh warga desa Ngliman. Hanya saja pelaksanaan/kebiasaan mandi yang sudah mentradisi itu tidak dilaksanakan tiap hari, tetapi dilaksanakan setahun sekali yang kemudian disebut Upacara Mandi/Sirama (Harimintadji, 1994:108). Selain sebagai penghormatan dan penghargaan terhadap Sang Dudo kebiasaan Upacara Siraman ini, dipercaya atau diyakini bahwa air terjun Sedudo adalah air suci yang mengandung banyak kasiat untuk kesehatan dan keberuntungan.

\section{METODE}

Kajian ini menggunakan pendekatan kualitatif, artinya data yang dikumpulkan berupa kata-kata yang bersumber dari:buku, naskah wawancara, catatan lapangan, dokumen pribadi, catatan memo, dan dokumen resmi lainya. Pendekatan kualitatif ini digunakan untuk menggambarkan data empirik tentang nilai-nilai sosial yang terkandung dalam pelaksanaan upacara ritual Siraman Sedudo yaitu dari berbagai macam, yaitu nilai toleransi, nilai kasih sayang, nilai gotong royong, nilai kerukunan, nilai kebersamaan, nilai kerjasama, dan nilai kekeluargaan.

Sumber data diperoleh dari informan, yaitu warga desa Ngliman yang mengikuti upacara ritual siraman sedud dan dokumentasi. Pengumpulan data dilakukan dengan observasi, wawancara, dan dokumentasi. Observasi dilakukan dengan melihat secara langsung yang sedang diteliti. Wawancara dilakukan dengan memberikan pertanyaan secara mendalam kepada informan berkaitan dengan tradisi upacara ritual siraman sesudo.

Kegiatan analilis data dilakukan melalui beberapa tahapan, yaitu: (1) reduksi data, kegiatan ini dilakukan dengan mengumpulkan semua data yang diperoleh di lapangan (data mentah) berupa hasil wawancara para subyek penelitian dan pengamatan secara langsung di desa Ngliman kecamatan Sawahan kabupaten nganjuk, (2) penyajian data, data disajikan dalam bentuk teks narasi atau uraian yang menyerupai cerita, (3) menarik kesimpulan.

\section{HASIL DAN PEMBAHASAN}

\section{Pelaksanaan Tradisi Upacara Ritual Siraman Sedudo}

Kata Sedudo berasal dari kata "Se" dan "Dudo". "Se" berarti satu, "Dudo" berarti orang yang sudah tidak mempunyai istri atau sengaja tidak beristri. Menurut kepercayaan penduduk Sang Dudo tersebut ialah orang yang membuka (Cikal Bakal) Desa Ngliman yang setiap hari digunakan sebagai tempat mandi Sang Dudo, maka tempat itu kemudian diberi nama Sedudo. Sebagai peghormatan dan penghargaan terhadap Sang Dudo yang dianggap sebagai cikal bakal desa Ngliman itu, kebiasaan mandi di air terjun diikuti oleh warga desa Ngliman. Hanya saja pelaksanaan/kebiasaan mandi yang sudah mentradisi itu tidak dilaksanakan tiap hari, tetapi dilaksanakan setahun sekali yang kemudian disebut Upacara Mandi/Siraman.

Bentuk siraman sedudo merupakan suatu Upacara ritual yang dilaksanakan setiap satu tahun sekali yaitu pada bulan Suro dan tepat pada tanggal 1 Suro dalam kalender Jawa atau dalam kalender Islam adalah bulan Muharram. Upacara Ritual sering disebut juga upacara keagamaan. Upacara ritual merupakan kegiatan yang dilakukan sekelompok masyarakat yang diatur dengan hukum masyarakat yang berlaku. Warga masyarakat desa Ngliman berbondong-bondong menyemarakkan dalam hal persiapan sebelum dan sesudah pelaksanaan upacara ritual mandi siraman.

Dalam menyemarakkan upacara siraman sedudo sebelum dan sesudah pelaksanaan adanya nilai-nilai sosial yang menjadi penggerak masyarakat. Nilai sosial merupakan gambaran mengenai apa yang diinginkan, pantas, berharga, memengaruhi perilaku sosial dari orang yang memiliki nilai tersebut (Handoyo dkk, 2015:44). Oleh karena Upacara Ritual Mandi Siraman Sedudo sudah beratus tahun lamanya maka hal ini sudah menjadi nilai yang mendarah daging bagi masyarakat desa Ngliman pada khususnya dan 
masyarakat Kabupaten Nganjuk pada umumnya. Nilai yang telah menjadi menjadi kepribadian dan kebiasaan sehingga seseorang melakukannya tanpa melalui proses berfikir atau proses pertimbangan (Anwar dkk, 2013:191).

Di lingkungan masyarakat desa Ngliman ternyata muncul beberapa nilai yang menjadi wujud dari pengalaman yang menjadi nilai sosial yang tumbuh dalam diri septiap jiwa individu, rasa simpati dan empati semakin tinggi sehingga menurunkan sikap egonya yang individualisti menjunjung nilai-nilai sosial dengan bekerjasama menyemarakkan dalam persiapan sebelum dan sesudah pelaksanaan upacara ritual mandi siraman. Nilai yang terkandung dalam pelaksanaan upacara ritual siraman sedudo yaitu terdiri dari berbagai macam di antaranya adalah nilai toleransi, nilai kasih sayang, nilai gotong royong, nilai kerukunan dan kebersamaan, nilai kerjasama, dan nilai kekeluargaan.

Tradisi ritual upacara siraman dilaksankan dengan menerapkan beberapa langkah yang sudah dilaksankan secara turun temurun. Beberapa kegiatan atau langkah pelaksanaan upacara ritual sebagai berikut (Harimintadji, 1994:110).

1. Upacara diawali dengan sajian tari sakral yang dibawakan 5 orang penari putri yang masingmasing membawa klenting (biasa digunakan untuk tempat air yang terbuat dari tanah liat). Tari tersebut menggambarkan permohonan kepada Tuhan YME agar upacara Siram/ Mandi Sedudo dapat berjalan lancar tanpa ada gangguan dan membersihkan kleting agar terhindar dari segala macam kotoran. (tarian ini diiringi dengan alat msik Jedor dan Tembang Sekar Mijil).

2. Dari arah timur 15 gadis berambut panjang yang berbusana indah serta anggun bak bidadari yang turun dari kahyangan, berjalan menuju di hadapan bapak bupati, 15 gadis tersebut duduk (jengkeng) memberi hormat/sembah mohon do'a restu.

3. Bapak Bupati memberikan klenting kepada 5 orang gadis yang duduk di depan, masingmasing sebuah secara bergilir, (klenting tersebut telah disiapkan oleh gadis yang juga berambut panjang yang berada di sebelah kiri bupati).

4. Setelah menerima klenting 5 gadis berdiri, kemudian berjalan perlahan-lahan diikuti oleh 10 gadis lainya menuju sendang/kolam di bawah grojogan Sedudo diiringi tembanga ilir-ilir yang dibawakan group tembang dan tabukan jedor.
5. Setelah sampai di kolam 5 gadis tersebut menyerahkan klenting, kepada 5 orang jejaka taruna yang sudah siap menunggu di bawah air terjun Sedudo.

6. Lima Orang jejaka mengisi klenting dengan air dari grojogan dan kemudian menyerahkan kembali kepada 5 orang gadis untuk dibawa ke tepi kolam (ke arah timur) yang diikuti oleh 10 gadis lain dan 5 jejaka taruna.

7. Air suci tersebut diserahkan kepada juru kunci makam desa Ngliman yang telah siap bersama sesepuh desa setempat.

8. Oleh juru kunci dan sesepuh desa air suci tersebut di bawa ke atas yang selanjutnya disimpan di makam desa Ngliman, sedangkan 5 gadis dan 5 jejaka taruna menuju ke tempat yang telah disediakan.

9. Sambutan dan peresmian mandi/Siraman Sedudo oleh Bupati Kabupaten Nganjuk.

10.Pembacaan do'a secara Islam.

11. Mandi bersama, dilanjutkan ziarah ke makam Kyai Ngliman.

\section{Wujud Pelestarian Nilai-Nilai Sosial dalam Tradisi Ritual Upacara Siraman Sedudo}

Berangkat dari berfikir mendalam secara filsafati dalam filosofi pelestarian didasarkan pada kecenderungan manusia untuk melestarikan nilainilai budaya pada masa yang telah lewat namun memiliki arti penting bagi generasi selanjutnya. Pelestarian secara umum dapat didefinisikan sebagai suatu usaha atau kegiatan untuk merawat, melindungi dan mengembangkan obyek pelestarian yang memiliki nilai guna untuk dilestarikan. Menurut kamus besar bahasa Indonesia KBBI Pelestarian adalah perlindungan dari kemusnahan atau kerusakan. Hal ini yang dimaksud usaha manusia untuk melestarikan nilai-nilai yang ada dalam masyarakat yang berupa nilai budaya yang sudah ada dari masa yang telah lewat yang memiliki nilai guna bagi masyarakat untuk dilestarikan dan dilindungi eksistensinya.

Nilai adalah keyakinan yang membimbing seseorang untuk melakukan atau tidak melakukan sesuatu dalam kehidupanya (Liliweri, 2014:77). Dalam mewujudkan pelestarian nilai-nilai sosial warga desa Ngliman berbondong-bondong menyemarakkan dalam hal persiapan sebelum dan sesudah pelaksananan Upacara Ritual Mandi Siraman Sedudo dengan mengesampingkan sikap egonya yang individualistik dan merasa ikut ber 
empati dan ber simpati dalam Pelaksanaan Upacara Ritual Siraman Sedudo. Menurut Rokeach nilai adalah salah satu unsur dasar pemebentukan orientasi budaya, nilai melibatkan konsep budaya yang menganggap sesuatu yang menganggap sesuatu itu sebagai baik atau buruk, benar atau salah, adil atau tidak adil, cantik atau jelek, bersih atau kotor, berharga atau tidak berharga, cocok atau tidak, dan baik atau kejam (Liliweri, 2014:55).

Sesuatu dianggap bernilai apabila pilihan diarahkan pada yang baik, menarik, dan diperbolehkan karena memiliki manfaat bagi manusia. Hal ini sesuai dengan Selain sebagai penghormatan dan penghargaan terhadap Sang Dudo kebiasaan Upacara Siraman ini, dipercaya atau diyakini bahwa air terjun Sedudo adalah air suci yang mengandung banyak kasiat untuk kesehatan dan keberuntungan (Harimintadji, 1994:109). Nilai menurut Anwar dan adang; 1) Nilai merupakan konsepsi-konsepsi abstrak yang ada dalam diri manusia, mengenai segala hal yang dianggap baik dan yang dianggap buruk; 2) Nilai merupakan prinsip etika yang mengikat, karena dipegang kuat oleh individu atau kelompok sehingga dapat mempengaruhi perilakunya; 3) Nilai berkaitan dngan baik dan buruk, yang dikehendaki; Nilai membentuk norma yatu aturan-aturan yang harus dipatuhi oleh setiap anggota dalam suatu masyarakat yang memiliki sanksi positif maupun negatif(Anwar, Yesmil \& Adang, 2013:188-189). Nilai tidak akan terlepas dari masyarakat dan kebudayaan, nilai merupakan suatu keyakinan yang ada dalam setiap individu manusia oleh karenanya nilai merupakan hal yang urgent (penting), karena nilai menjadi suatu panutan, pembimbing bagi masyarakat dalam interaksinya dengan masyarakat lain oleh karenanya nilai mempunyai peran kompleks bagi terciptanya norma atu aturan-aturan yang ada dalam masyarakat.

Menurut Jimenez (Liliweri, 2014) menyebutkan beberapa tipe nilai yaitu; nilai pribadi, nilai keluarga, nilai sosial, nilai material, nilai spiritual, dan nilai moral. Nilai-nilai budaya ditentukan melalui beberapa sumber antara lain: adaptasi dengan lingkungan, faktor-faktor sejarah, evolusi sosial dan budaya, kontak dengan kelompok lain, pesan-pesan dalam keluarga kepada anak-anak, certita tentang kebudayaan, masyarakat melalui pemberian hukuman dan ganjaran, pendidikan agama, pendidikan formal, dan kelompok inti (Liliweri, Alo, 2014:57). Sedangkan menurut
Notonagoro (2014:74) membedakan nilai menjadi tiga macam, yaitu: nilai material yang meliputi berbagai konsepsi mengenai segala sesuatu yang berguna bagi jasmani manusia, nilai vital yang meliputi berbagai konsepsi yang berkaitan dengan segala sesuatu yang berguna bagi manusia dalam melaksanakan aktivitas, nilai kerohanian yang meliputi konsepsi yang berkaitan dengan segala sesuatu yang berhubungan dengan kebutuhan rohani manusia seperti; nilai kebenaran yang bersumber dari akal manusia, nilai keindahan yang bersumber pada unsur perasaan, nilai moral yang bersumber pada kehendak, dan nilai keagamaan bersumber dari wahyu Tuhan.

Sosial merupakan serangkaian konsepkonsep dasar atau pengetahuan dasar-dasar ilmu sosial secara interdisiplin atau multidisiplin dipergunakan seabgai alat bagi pendekatan dan pemecahan problema-problema yang ditimbul dan berkembang dalam masyarakat (Ahmadi dkk, 1991:3). Nilai sosial adalah sejumlah sikap perasaan ataupun anggapan terhadap suatu hal mengenai baik-buruk, benar salah,, patut tidak patut, mulia hina, maupun penting tidak penting (Handoyo dkk, 2015:43).

Bentuk nilai sosial yang ada pada masyakat desa Ngliman merupakan perwujudan dari pengalaman nilai sosial yang tumbuh pada jiwa individu, maka simpati dan empati dari sesamanya juga semakin tinggi. Sehingga individu tidak lagi mementingkan egonya, namun dengan menjunjung tinggi nilai-nilai sosial, ia juga memperhatikan kepentingan bersama. Nilai-nilai dibagi menjadi beberapa sub, yaitu: nilai toleransi, nilai kasih sayang, nilai gotong-royong, nilai kerukunan, nilai kerjasama, dan nilai kekeluargaan (Zubaedi, 2006:13).

Toleransi menurut kamus besar bahasa Indonesia (KBBI), diartikan sebagai sifat atau sikap toleran. Toleransi menurut istilah berarti menghargai, membiarkan pendirian pendapat, pandangan, kebiasaan, membolehkan, kepercayaan, kelakuan dan sebagainya. Ttoleransi adalah sikap saling menghargai, dengan pengertian untuk tujuan perdamaian. Pada intinya toleransi berarti suatu sifat dan sikap menghargai dan sifat serta sikap tersebut harus muncul diwujudkan oleh individu dalam kelompok maysarakat untuk kegitan Tradisi Upacara Ritual Siraman Sedudo.

Kasih sayang menurut kamus besar bahasa Indonesia (KBBI) merupakan perasan sayang, perasaan cinta atau perasan suka kepada 
seseorang atau terhadap sesuatu. Kasih sayang bersumber dari unsur rasa dalam diri manusia, yngkapan perasaan yang diberikan akal dan akan direalisasikan dalam bentuk perbuatan atau tingkah laku yang bertanggung jawab. Kasih sayang yang disertai dengan tanggung jawab menciptakan suatu keserasian, kedamaian, dan keseimbangan antar sesame manusia, antar manusia dan alam lingkungan, serta antara manusia dengan Tuhan.

Gotong royong merupakan kata serapan dari bahasa Jawa yaitu gotong dan royong. Kata gotong dapat dipadankan dengan kata bersama-sama. Secara sederhana gotong royong berarti mengangkat sesuatu secara bersama-sama. Dalam kamus besar bahasa Indonesia (KBBI), gotong royong merupakan aktifitas bekerja bersama-sama, bantu-membantu, tolongmenolong. Gotong royong sangat diperlukan dalam kaitanya mewujudkan kelompok maysarakat untuk kegitan Tradisi Upacara Ritual Siraman Sedudo.

Kerukunan adalah suatu keadaan dimana tercipta suatu keseimbangan sosial dalam masyarakat. Dari kata dasar rukun maka kerukunan bukan hanya sebagai suatu situasi atau kondisi semata tetapi lebih dari itu kerukunan mencerminkan suatu relasi yang mendalam antar individu atau kelompok dalam suatu tatanan kehidupan bermasyarakat atau beragama. Cakupan kerukunan dan kebersamaan diantaranya adalah: kerukunan dalam keluarga, kerukunan dalam hidup beragama, kerukunan dalam hidup bermasyarakat, kerukunan dalam berbudaya.

Kerjasama merupakan suatu proses sosial, yang didalamnya terdapat aktifitas atau kegiatan tertentu yang ditunjukkan untuk mencapai tujuan bersama dengan saling memahami aktifitas masing-masing. Aktifitas yang dimaksud disini tidak lain adalah aktifitas msyarakat desa Ngliman dalam sebelum, dalam proses dan sesudah Tradisi Upacara Ritual Siraman Sedudo. Kerjasama menurut kamus besar bahasa Indonesia (KBBI) adalah suatu kegiatan atau usaha yang dilakukan oleh beberapa orang dengan tujuan untuk mencapai tujuan bersama. Dengan kata lain aktifitas masyarakat desa Ngliman telah melakukan kerjasama dalam Tradisi Upacara Ritual Siraman Sedudo. Prnsip dari kerjasama antara lain; 1) Berorientasi pada tercpainya tujuan yang baik, 2) Memeperhatikan kepentingan bersama, 3) Prinsip saling meguntungkan.
Kekeluargaan menurut kamus besar bahasa Indonesia (KBBI) kekeluargaan berasal dari kata keluarga yang berarti dua atau lebih individu yang hidup dalam suatu rumah tangga karena adanya hubungan darah, perkawinan, atau adopsi. Mereka saling berinteraksi satu sama lain, mempunyai peran masing-masing dan menciptakan serta mempertahankan suatu budaya. Kekeluargan merupakan suatu perasaan yang dimilik oleh seseorang yang dirasakan ketika seseorang keluarga merasakan rasa seperti yang dirasakan ketika keluarganya merasakan atau bisa dikatakan empati yaitu keadaan mental yang membuat seseorang merasa atau mengindentifikasi dirinya dalam keadaan perasaan atau pikiran yang sama dengan orang lain atau kelompok.

\section{SIMPULAN}

1. Upacara ritual di Sedudo dilaksankan melalui langkah berikut: (1) tari sakral yang dibawakan 5 orang penari putri dengan membawa klenting, (2) 15 gadis berambut panjang yang berbusana indah duduk (jengkeng) memberi hormat/ sembah mohon do'a restu, (3) Bupati memberikan klenting kepada 5 orang gadis yang duduk di depan, (4) 5 gadis berdiri, kemudian berjalan perlahan-lahan diikuti oleh 10 gadis lainya menuju sendang/kolam di bawah grojogan Sedudo, (5) 5 gadis menyerahkan klenting kepada 5 orang jejaka taruna di bawah air terjun Sedudo, (6) 5 orang jejaka mengisi klenting dengan air dari grojogan dan menyerahkan kembali kepada 5 orang gadis untuk dibawa ke tepi kolam, (7) air suci diserahkan kepada juru kunci, (8) juru kunci dan sesepuh desa menyimpan air suci di makam desa, (9) sambutan dan peresmian mandi/ siraman Sedudo oleh Bupati, (10) pembacaan do'a, (11) mandi bersama, dilanjutkan ziarah ke makam Kyai Ngliman.

2. Bentuk nilai sosial yang ada pada masyakat di Desa Ngliman merupakan perwujudan dari pengalaman nilai sosial yang tumbuh pada jiwa individu, maka simpati dan empati dari sesamanya juga semakin tinggi. Sehingga individu tidak lagi mementingkan egonya, namun dengan menjunjung tinggi nilai-nilai sosial, ia juga memperhatikan kepentingan bersama. 


\section{DAFTAR RUJUKAN}

Ahmadi, Abu, dkk, 1991. Pengantar Ilmu Sosial Dasar. Jakarta: PT. Rineka Cipta.

Anwar, Yesmil \&Adang, 2013. Sosiologi Untuk Universitas. Bandung : PT. Refika Aditama.

Comans, M, 1987. Manusia Daya: Dahulu Sekarang Masa Depan. Jakarta: PT Gramedia.

Handoyo, Eko, dkk, 2015. Studi Masyarakat Indonesia. Yogyakarta: PT. Ombak

Harimintadji, 1994. Nganjuk dan Sejarahnya.Jakarta: Pustaka Kartini

Koentjaraningrat, 2015. Kebudayaan, Mentalitas dan Pembangunan. Jakarta : PT.Gramedia Pustaka Utama.
Koentjaraningrat, 1980. Sejarah Teori Antropologi. Jakarta : Universitas Indonesia.

Koentjaraningrat, 1967. Beberapa Pokok Antropologi Sosial. Jakarta : Dian Rakyat

Liliweri, Alo, 2014. Pengantar Studi Kebudayaan. Bandung: PT. Nusa Media

Rohmah, Luluk Nur, 2015. Studi Tentang Pelaksanaan Upacara Ritual Siraman

Satu Suro di Desa Ngliman Kecamatan Nganjuk Sawahan Kabupaten Nganjuk.Kediri : Universitas Nusantara PGRI Kediri.

Zubaedi, 2006. Pendidikan Berbasis Masyarakat. Yogyakarta: Pustaka 